\title{
Research with fetal tissue
}

SIR-Keith Crutcher's bizarre letter on research with fetal tissue (Nature 343, 10; 1990) has prompted me to join this debate. Abortion has a negative moral import to most people, and most would also agree that the gravity of offence rises to that of murder by the end of gestation. Before that, however, a pregnant individual may weigh the moral costs of abortion against the moral costs of having an unwanted child. These can include the effects on the mother's life, the effects of abuse and/or inadequate support on the child and the legal and economic costs visited upon society by the adult that emerges. Because such moral calculations vary greatly among reasonable people and societies, decisions on abortion are best left to the individuals involved. Laws are one means by which society promulgates common moral beliefs. The historical and current lack of a moral consensus on abortion is exactly why abortion is not now illegal.

The same logic may be applied to the question of research with fetal tissue. As Crutcher admits, the legality of abortion in effect legalizes the existence of fetal tissues and their availability for research. What happens to them after that should be decided by the individual scientist. Those with moral objections either to abortion or to the use of fetal tissue need not accept such work personally; others may decide that the moral benefits obtained from such research outweigh the moral costs. The scientific community generally favours research with fetal tissue and human embryos; the specific ban on its funding by the US Department of Health and Human Services is therefore inconsistent with society's lack of consensus on abortion or fetal research, as well as with the opinions of most individuals in this community. As we all know, funding decisions on research projects are best made on the basis of peer review of their scientific merits.

The possibility of finding a moral consensus on abortion in the future is only decreased by the polarizing language and tactics adopted by those at either extreme, including Crutcher's deliberate attempt to provoke sensory disgust. It stands to reason that this lack of consensus necessarily favours the pro-choice side. Anti-abortionists should therefore be more motivated to compromise, and should abandon untenable, absolute positions. One possible compromise is for elective abortions to be legal only in an earlier and shorter period of pregnancy, such as $0-13$ weeks. This preserves most of the rights of a mother to choose, but clearly segregates the early embryo or fetus from those near separate viability ( 25 weeks). In addition, anti-abortion groups may want to devote their energies to preventing unwanted pregnancies in the first place.

ROBERT BOOKSTEIN

Department of Pathology M-012,

School of Medicine,

University of California, San Diego,

La Jolla, California 92093, USA

\section{Shockley defamed}

SIR-That Nature saw fit to publish such abusive treatment of the late William Shockley, not once but twice, strikes me as a disgrace.

First, the obituary on Shockley (Nature 341, 190; 1989) is clownishly signed with the obvious pseudonym "H. Kallikak" (harking back to the ancient "Jukes" and "Kallikaks" studies of 'feeblemindedness' by Dugdale and Goddard). Scarcely 12 per cent of its wordage is devoted to Shockley's path-breaking achievements in physics (for which he won the Nobel prize), while all the rest is a grossly opinionated disparagement of what the authors refers to as the "affliction" Shockley developed after becoming a laureate, namely his interest in IQ, genetics, population differences and their possible longterm social consequences. As one who has paid close attention to everything Shockley published on these topics for more than 20 years, I must say that in my opinion 'Kallikak's' comments give a muddled and biased view of Shockley's thinking in this area.

Second, Frederick Seitz's pretended defence of Shockley $(\mathbf{3 4 2}, 474 ;$ 1989) only adds injury to insult, essentially going along with ' $\mathrm{H}$. Kallikak' but excusing Shockley's "ill-conceived concentration on socio-genetic matters" as possibly the result of an automobile collision, a conjecture that leads Science's capsule summary $(247,25 ; 1990)$ of Seitz's letter in Nature to question: "Could William Shockley's unpopular ideas about race and IQ have been the result of a blow to the head?" This surely must be the farthest outpost of ad hominem criticism of a scientist's ideas. As one who knew Shockley well during the past two decades of his life, I can testify that, in matters analytical, mathematical, statistical and scientific, Shockley was a remarkably clear thinker and absolutely as sharp as they come. I question that anyone who had any intellectual commerce with Shockley during this period could have any doubt that he was immensely bright and quick of mind.

'Kallikak' and Seitz both seem unaware that their sweeping dismissal of the basis of Shockley's ideas on IQ, genetics and race would today represent a minority view among scientists and scholars in the fields most related to the study of these topics. Shockley believed that present-day
IQ tests are valid measures of intelligence, are racially unbiased predictors of educational achievement and job performance, that individual differences in IQ have substantial heritability and both genetic and environmental factors are involved in the difference between the IQ distributions in the black and white populations. On each one of these points, a majority of experts in the relevant fields express the very same opinions, as shown in a recent large-scale survey (M. Snyderman \& S.L. Rothman The IQ Controversy: The Media and Public Policy. Transaction Books, 1988).

ARTHUR R. JENSEN

University of California,

Berkeley, California 94720, USA

\section{Current opinion}

SIR-Peter Coles (Nature 343, 399; 1990) is pessimistic about the present practicability of electric cars when he says, correctly, that to replace the small family petrol-engined car a daily maximum range of around $500 \mathrm{~km}$ would be needed. The $100 \mathrm{~km}$ now achievable would, however, be quite adequate for the second car of many two-car families, used for shopping and taking the children to school. With good advertising, and perhaps reduced car tax, the demand should cover as many cars as the industry can produce during the period needed for a major improvement in performance.

46 Vernon Road,

J. M. FrEMLIN

Edgbaston,

Birmingham B16 9SH, UK

\section{Inverse tomograph}

SIR-Daedalus has suggested (Nature $343,516 ; 1990)$ that construction of an inverse tomograph could sharpen the accuracy of radiotherapy. You may be interested to know that the details of how to compute the intensities and directions of the beams were worked out here during 1989 using an optimization method which exactly mirrors the X-ray tomography problem ${ }^{1}$. This idea was also in the mind of Professor Anders Brahme at Sweden's Karolinska Institute ${ }^{2}$

But there are snags. To do the job properly, some beam intensities would need to be negative. If Daedalus could design a machine that could achieve this, we should like to see it. A machine that could accurately deliver positive multiple-element beams remains the radiotherapy physicist's dream.

Joint Department of Physics,

S. WebB

Royal Marsden Hospital,

Sutton,

Surrey SM2 5PT, UK

1. Webb, S. Phys. Med. Biol. 34, 1349-1370 (1989)

2. Brahme, A. Radiother. Oncol. 12, 129-140 (1988). 